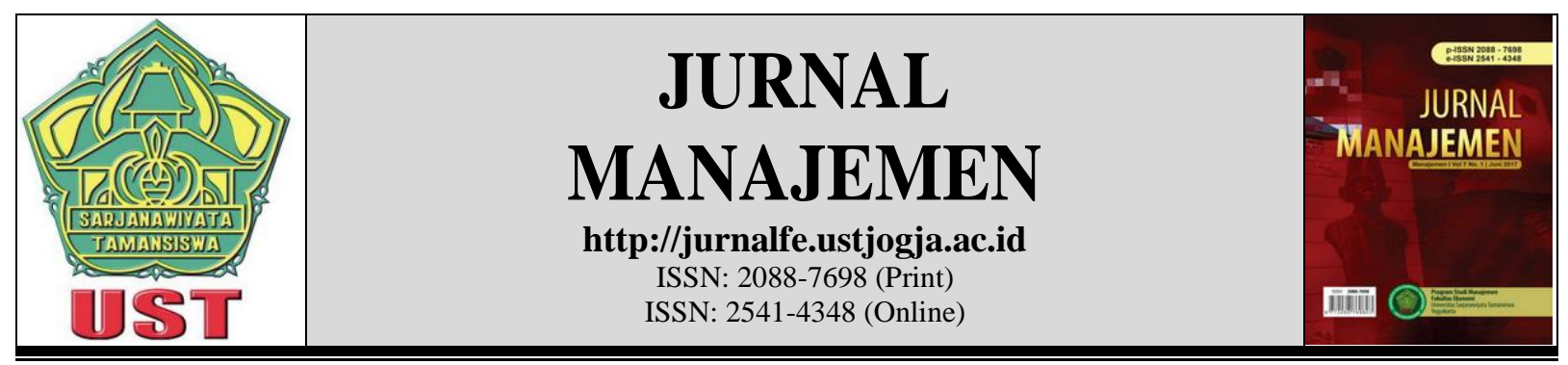

\title{
PENGARUH BRAND NAME DAN COUNTRY OF ORIGIN TERHADAP PERSEPSI KUALITAS DAN NIAT BELI MINUMAN RINGAN BERKARBONASI
}

\section{Adhi Prakosa}

\author{
Universitas PGRI Yogyakarta
}

Korespondensi:adhi27prakosa@gmail.com

\begin{tabular}{ll}
\hline Informasi Naskah & \multicolumn{1}{c}{ Abstrak } \\
\hline Diterima: & This study aims to test relationships between brand name and \\
11 November 2017 & country of origin. Independent variable is brand name and country \\
Revisi: & of origin. The dependent variable is perceived quality and \\
19 November 2017 & intention to buy. The data collection is done directly by using a \\
Terbit: & survey questionnaire. Hypothesis testing is done using simple \\
1 Desember 2017 & regression with SPSS version 22.0. Results can be concluded that \\
\hline Kata Kunci: Brand & brand name and country of origin affect the perception of quality \\
Name, Country of & to the product and consumer purchase intention. \\
Origin, Perceived & \\
Quality, Intention to & \\
Buy &
\end{tabular}

\section{PENDAHULUAN}

Kualitas merupakan salah satu alasan konsumen membeli produk. Kualitas tinggi dipersepsikan oleh konsumen sebagai hasil produksi negara yang mempunyai teknologi tinggi. Saat ini perdagangan antar negara terbuka lebar, dan distribusi barang semakin mudah. Negara maju seperti Amerika Serikat, Jerman, Jepang atau Korea Selatan dikenal sebagai penghasil produk-produk yang diekspor ke seluruh dunia. Didukung oleh kampanye pemasaran dan periklanan untuk mendukung citra merek, merek-merek dari negara tersebut populer di seluruh dunia. Kemajuan teknologi informasi membuat media periklanan secara cepat dapat diakses oleh masyarakat. Pasar dipenuhi oleh produk-produk yang ditawarkan ke calon konsumen. Oleh sebab itu, pemasar menghadapi persaingan yang ketat dalam memasarkan produknya. Menurunnya hambatan perdagangan antar negara menghadirkan konsekuensi yaitu produk dan jasa yang diperdagangkan lintas negara lebih banyak dibandingkan era sebelumnya, sehingga citra negara asal dapat dimanfaatkan sebagai pembeda kompetitif (Dinnie, 2003). Dampaknya, produk dari negara maju memenuhi pasar negara-negara berkembang. 
Produk-produk berteknologi tinggi dari negara maju masuk ke negara-negara lain. Di Indonesia, persepsi konsumen terpengaruh oleh citra merek dan negara asal produk. Misalnya produk smartphone dari negara Amerika Serikat dipersepsikan berkualitas, dan produk smartphone dari negara China dipersepsikan memiliki harga yang murah. Ini adalah pengaruh dari country of origin atau negara asal produk atau merek. Nama merek (brand name) dan produk adalah hal yang berbeda. Produk ditawarkan ke pasar dan digunakan untuk memenuhi kebutuhan dan keinginan, sementara nama merek adalah nama atau simbol yang diasosiasikan dengan produk atau jasa untuk membedakan dengan produk atau jasa lainnya. Saat konsumen membeli produk mereka secara umum mempertimbangkan merek produk. Merek yang memiliki citra merek baik, membuat konsumen memiliki persepsi bahwa kualitas untuk produk tersebut juga tinggi. Penelitian terdahulu banyak membahas mengenai citra merek yang mempengaruhi keputusan pembelian konsumen.

Merek yang populer dan citranya baik dipersepsikan oleh konsumen merupakan merek dari negara maju. Jika dihubungkan dengan citra negara asal, misalnya merek mobil dari negara Jerman dikenal sebagai penghasil produk otomotif berkualitas dunia. Country of origin dapat dipahami secara sederhana sebagai negara asal dari suatu produk. Country of origin akan mempengaruhi perilaku konsumen. Konsumen lokal akan terpengaruh secara psikologis jika menemukan merek yang berasal dari luar negeri. Dalam salah satu penelitian mengenai country of origin, negara Jepang dipersepsikan oleh konsumen di Asia Tenggara yaitu negara Malaysia sebagai negara yang memiliki kualitas produk tertinggi, diikuti oleh Jerman dan Amerika Serikat (Ghazali, Said Othman, Zahiruddin Yahya, \& Sarif Ibrahim, 2008). Untuk itu, dalam persaingan bisnis global, pemasar dapat memanfaatkan keunggulan dari negara asal untuk bersaing dan mempengaruhi aspek psikologis calon konsumen.

Penelitian di Indonesia mengenai country of origin menguji pengaruh variabel ini terhadap produk elektronik (Achmad \& Istiqomah, 2014; Listiana, 2013). Untuk kategori produk makanan dan minuman, misalnya keputusan pembelian pada produk susu di Indonesia (Krisjanti, 2007). Beberapa penelitian lainnya dalam kategori produk susu adalah penelitian untuk menguji pengaruh country of origin produk Selandia Baru pada konsumen China (Luo, 2011). Pada kategori minuman anggur (wine) penelitian mengenai pengaruh country of origin ini juga sudah dilakukan (Xiaoling $\mathrm{Hu}$, Leeva Li, Charlene Xie, 2008). Menurut literatur sebelumnya, country of origin akan mempengaruhi perilaku konsumen. Di Indonesia, konsumen lokal cenderung terpengaruh secara psikologis jika menemukan merek atau produk yang berasal dari luar negeri. Menggunakan produk dengan konteks yang berbeda untuk menguji pengaruh country of origin akan menarik dilakukan. Beberapa penelitian sebelumnya menggunakan kategori produk elektronik, dan beberapa penelitian di Asia menggunakan kategori makanan atau minuman seperti produk susu dan minuman anggur (wine). Untuk itu, penggunaaan produk pada kategori minuman akan menarik untuk diuji pengaruhnya terhadap evaluasi konsumen. Penelitian ini akan menguji pengaruh nama merek, dan country of origin pada persepsi kualitas dan niat beli konsumen untuk minuman ringan berkarbonasi yaitu Coca Cola. Merek Coca Cola dikenal sebagai ikon dari negara Barat. Distribusi produk minuman ringan berkarbonasi ini juga sudah tersebar ke seluruh dunia, dan populer sebagai minuman yang berasal dari negara Amerika Serikat. Di Indonesia, Coca Cola dapat dengan mudah ditemui di supermarket atau minimarket.

\section{KAJIAN PUSTAKA DAN HIPOTESIS Brand Name dan Country of Origin}

Nama merek (brand name) dan logo merupakan aset tak berwujud yang sangat bernilai 
bagi perusahaan, merek yang kuat menciptakan nilai (value), baik untuk perusahaan maupun konsumen. Di masa sekarang, semakin banyaknya produk yang ditawarkan kepada konsumen membuat mereka tidak bisa menilai fungsi dari produk, untuk itulah merek dan harga dapat berfungsi dalam menciptakan persepsi pelanggan, merek membantu konsumen untuk mengidentifikasi produk, dan memberikan informasi berguna yang berkaitan dengan kualitas sebuah produk (Ardestani \& Afshar, 2015). Nama merek yang berasal dari negara maju memiliki persepsi kualitas tinggi di benak konsumen. Hal ini dipengaruhi oleh negara asal atau country of origin merek atau produk. Penelitian awal mengenai country of origin sudah dilakukan sejak 50 tahun yang lalu (Listiana, 2013). Penelitian terdahulu menemukan hubungan positif antara country of origin dan persepsi kualitas dan niat beli. Country of origin adalah fenomena saat konsumen mengevaluasi produk berdasarkan penilaian tentang negara asal (Chryssochoidis et al, 2007 dalam Järveläinen, 2012).

Negara asal dapat mempengaruhi keputusan dan perilaku konsumen. Penelitian dalam bidang pemasaran dengan konteks produk yang berbeda membuktikan hal ini. Dalam perkembangannya, penelitian dengan tema country of origin dilakukan di berbagai negara. Penelitian merek Uniqlo dari Jepang yang berada di Indonesia membuktikan negara asal mempengaruhi citra merek, dan keputusan pembelian (Suria, Kusumawati, \& Pangestuti, 2016). Penelitian Xiaoling Hu, Leeva Li, Charlene Xie (2008) menguji pengaruh country of origin untuk pembelian minuman anggur di negara China khususnya di kota Shanghai dan Hangzhou. Minuman anggur sebagai produk mewah mempengaruhi gaya hidup warga menengah China sehingga konsumen membeli dari negara asal anggur berkualitas yaitu di kawasan Eropa, misalnya Perancis. Di sisi lain, penelitian mengenai country of origin pada produk susu impor di Indonesia ternyata memberikan hasil yang berbeda, harga berperan besar memberikan pengaruh terhadap variabel niat beli, sedangkan variabel country of origin tidak memberikan pengaruh yang signifikan pada terbentuknya niat beli (Krisjanti, 2007). Perbedaan konteks penelitian mengenai country of origin ini menarik untuk dikaji lebih lanjut. Untuk itu, penelitian ini mencoba menggunakan produk minuman ringan berkarbonasi untuk menguji pengaruh brand name dan country of origin pada konsumen.

\section{Hipotesis 1: Brand name berpengaruh positif pada persepsi kualitas terhadap produk}

\section{Persepsi Kualitas dan Niat Beli}

Persepsi kualitas adalah perasaan keseluruhan tentang merek berdasarkan dimensi yang melekat pada produk termasuk karakteristik seperti keandalan dan kinerja, sehingga persepsi kualitas tidak berwujud (Aaker, 1991). Penelitian Listiana (2013) menemukan bahwa terdapat hubungan antara country of origin dan persepsi kualitas (perceived quality), hasil penelitian menunjukkan terdapat penilaian positif tentang negara asal dan kualitas yang dirasakan. Penelitian mengenai persepsi kualitas dan country of origin banyak dilakukan. Dinnie (2003) menyatakan, penelitian Heslop dan Wall (1985) berupaya untuk menyelidiki pengaruh demografi yaitu jenis kelamin terhadap country of origin, bahwa wanita cenderung memberikan penilaian lebih tinggi dibandingkan laki-laki dalam hal persepsi kualitas yang dirasakan. Menurut teori, hubungan antara citra merek dan brand equity dimediasi oleh persepsi kualitas (Severi \& Ling, 2013).

Persepsi kualitas secara langsung mempengaruhi niat beli konsumen. Sebelum melakukan pembelian, konsumen memiliki persepsi mengenai kualitas, harga, dan gaya produk, baru kemudian setelah menggunakan produk maka niat beli akan menurun dikarenakan ada hubungan langsung yang mempengaruhi satu sama lain (Saleem, Ghafar, Ibrahim, Yousuf, \& 
Ahmed, 2015). Konsumen menilai positif hubungan antara negara asal, dan memberikan penilaian positif tentang persepsi kualitas yang dirasakan (Listiana, 2013). Persepsi kualitas diharapkan dapat mengarahkan pelanggan ke pembelian berulang, sehingga pemahaman yang lebih baik tentang hubungan antara kualitas produk yang dirasakan dan keterlibatan produk, kepuasan konsumen dan niat beli dapat membantu untuk mengembangkan model pengambilan keputusan konsumen (Tsiotsou, 2005).

Teori mengenai variabel niat beli dijelaskan oleh Qader \& Zainuddin (2010) yang membahas mengenai niat perilaku (behavioral intention) yang dipengaruhi oleh tiga macam pertimbangan, yaitu keyakinan perilaku (behavioral belief), keyakinan normatif (normative belief), dan keyakinan kontrol (control belief). Keyakinan perilaku adalah keyakinan tentang kemungkinan hasil dari perilaku dan evaluasi. Keyakinan normatif adalah keyakinan tentang harapan normatif orang lain dan motivasi untuk mematuhi harapan. Keyakinan kontrol adalah keyakinan tentang adanya faktor-faktor yang dapat memfasilitasi atau menghambat kinerja perilaku. Dapat dijelaskan secara singkat, jika semakin menguntungkan sikap dan norma subjektif, dan semakin besar kontrol yang dirasakan, maka semakin kuat niat seseorang untuk melakukan suatu perilaku. Dalam hal keputusan pembelian konsumen, pada tahapan evaluasi seorang konsumen akan memberi peringkat terhadap merek dan bentuk niat beli mereka. Konsumen kemudian akan membeli merek yang paling disukai, akan tetapi ada faktor lain yang terkadang mempengaruhi niat beli dan keputusan untuk membeli, yaitu sikap orang lain dan situasi yang tidak terduga.

Hipotesis 2: Country of origin berpengaruh positif pada persepsi kualitas terhadap produk Hipotesis 3: Country of origin berpengaruh positif pada niat beli konsumen

\section{Model Penelitian}

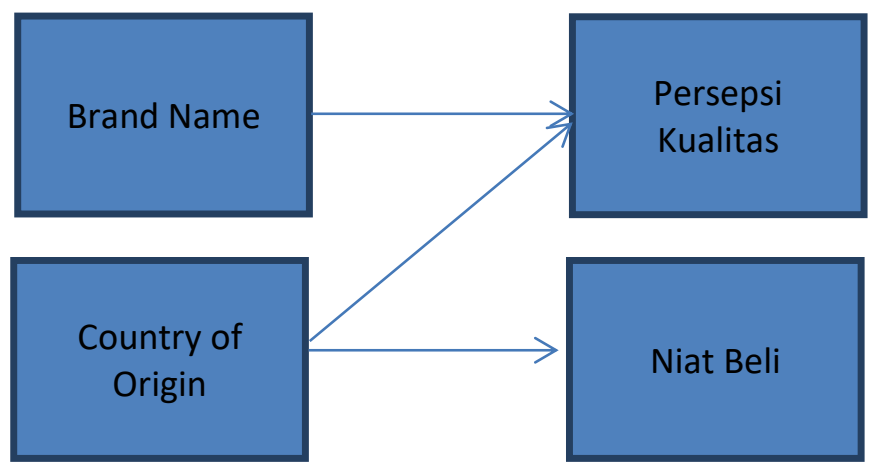

Gambar I Model Penelitian

\section{METODE PENELITIAN}

\section{Desain Penelitian}

Penelitian ini bersifat kuantitatif. Jenis penelitian adalah confirmatory research yang bertujuan menguji hipotesis berdasarkan teori yang sudah ada. Metode penelitian survei dilakukan untuk mengumpulkan data melalui daftar pertanyaan pada kuesioner. Penelitian ini memfokuskan pada empat variabel yaitu brand name, country of origin, persepsi kualitas dan niat beli konsumen. Skala pengukuran yang digunakan adalah skala Likert 5 poin, butir-butir pertanyaan diadaptasi dari penelitian yang pernah dilakukan oleh Järveläinen (2012) dan 
Ghazali et al., (2008). Responden penelitian akan diminta untuk mengisi kuesioner untuk mendapatkan tanggapan dari pertanyaan kuesioner. Kuesioner penelitian berisi item-item pertanyaan yang memberikan gambaran mengenai variabel-variabel yang diteliti.

\section{Populasi dan sampel}

Populasi adalah jumlah keseluruhan elemen yang akan diteliti (Cooper \& Schindler, 2006). Populasi yang menjadi subyek penelitian ini adalah konsumen minuman ringan berkarbonasi di Yogyakarta. Sampel adalah bagian dari populasi yang akan diteliti. Sampel dari penelitian ini adalah konsumen minuman ringan berkarbonasi yang pernah membeli minuman ringan berkarbonasi Coca-Cola. Ukuran sampel paling sedikit berjumlah 20 untuk masingmasing variabel (Hair, Black, \& Babin, 2006). Penelitian ini menggunakan tiga variabel, sehingga jumlah sampel minimum yang harus dipenuhi adalah sebanyak 60 responden $(3 \times 20)$. Mengantisipasi kekurangan data maka jumlah sampel yang diambil pada penelitian ini sebanyak 120 responden.

\section{Metode pengambilan sampel}

Metode penelitian ini adalah non-probability sampling, dengan teknik purposive sampling. Artinya tiap anggota tidak memiliki kesempatan yang sama untuk dipilih sebagai sampel (Cooper \& Schindler, 2006). Purposive sampling dipilih untuk mendapatkan responden dengan kriteria tertentu. Metode pengambilan sampel dengan teknik observasi. Responden yang dijadikan sampel adalah konsumen yang pernah melakukan pembelian minuman ringan berkarbonasi.

Untuk memenuhi kriteria ini, saat penyebaran kuesioner terdapat pertanyaan screening: “Coca-Cola adalah merek minuman ringan berkarbonasi yang berasal dari negara mana?" dan "Apakah anda pernah membeli Coca Cola?". Jika jawaban responden adalah Ya maka responden tersebut memenuhi kriteria untuk menjadi sampel penelitian, sebaliknya jika jawabannya Tidak maka responden tersebut tidak memenuhi kriteria untuk menjadi sampel penelitian.

\section{Analisis Data}

Uji validitas digunakan untuk memastikan bahwa instrumen dalam kuesioner dapat digunakan untuk mengukur apa yang hendak diukur secara tepat dan benar. Uji validitas dalam penelitian ini menggunakan analisis faktor. Uji reliabilitas menggunakan metode Cronbach's alpha dengan bantuan program SPSS. Nilai koefisien minimal sebesar 0,60 adalah nilai yang dapat diterima (Hair et al., 2006). Penelitian ini menggunakan nilai koefisien minimal 0,60. Penelitian yang baik apabila nilai Cronbach's alpha semakin mendekati nilai 1. Uji hipotesis dilakukan menggunakan analisis regresi linier sederhana, dengan bantuan program SPSS 22 .

\section{HASIL DAN PEMBAHASAN \\ Karakteristik Partisipan}

Kuesioner disebarkan secara online, dan mendapatkan 164 tanggapan. Setelah melalui analisis data, ditemukan bahwa data yang memenuhi untuk dianalisis lebih lanjut sebanyak 123 kuesioner, sebanyak 41 kuesioner tidak dipakai dalam analisis karena tidak lengkap dan tidak lolos tes screening pertanyaan.

Partisipan adalah mahasiswa program studi Manajemen Universitas PGRI Yogyakarta. Dari 123 data, partisipan pria berjumlah 44 orang $(35,8 \%)$ dan partisipan wanita berjumlah 79 orang $(64,2 \%)$. Berdasarkan usia, sebanyak 9 orang $(7,3 \%)$ berusia antara 15-19 tahun, 
sebanyak 103 orang $(83,7 \%)$ berusia $20-24$ tahun, sebanyak 6 orang $(4,9 \%)$ berusia $25-29$ tahun, sebanyak 2 orang $(1,6 \%)$ berusia $30-34$ tahun, dan sebanyak $3(2,4 \%)$ orang berusia lebih dari 34 tahun. Jumlah pendapatan per bulan responden berjumlah antara Rp500.000,00Rp1.000.000,00 sebanyak 52 orang (42,3\%), antara Rp1.000.000,00-Rp1.500.000,00 sebanyak 33 orang $(26,8 \%)$, antara Rp1.500.000,00-Rp2.000.000,00 sebanyak 17 orang (13,8\%), antara Rp2.000.000,00-Rp2.500.000,00 sebanyak 10 orang $(8,1 \%)$, dan lebih dari Rp2.500.000,00 sebanyak 11 orang $(8,9 \%)$.

\section{Analisis Validitas dan Reliabilitas}

Pengujian validitas digunakan untuk memastikan bahwa instrumen dalam kuesioner dapat digunakan untuk mengukur apa yang hendak diukur secara tepat dan benar. Pengujian validitas dalam penelitian ini menggunakan analisis faktor. Hasil pengujian menunjukkan nilai KMO dan Bartlett's Test of Sphencity berdasarkan analisis faktor adalah sebesar 0,879 dan tingkat signifikansi 0,000 Berdasarkan hal tersebut maka semua variabel dapat dianalisis lebih lanjut karena telah memenuhi kriteria yang telah ditetapkan.

Seluruh variabel dapat dianalisis lebih lanjut karena telah memenuhi kriteria yang telah ditetapkan yaitu nilai KMO lebih besar dari 0,5 dan Bartlett's Test of Sphericity dengan tingkat signifikansi $\leq 0,01$. Kemudian dilakukan analisis faktor untuk menguji validitas butir-butir pertanyaan dari keseluruhan variabel dilakukan dengan menentukan 4 (empat) faktor sebagai batasan jumlah faktor sesuai dengan jumlah variabel yang digunakan. Hasilnya adalah butirbutir pertanyaan mengelompok dan membentuk 4 (empat) faktor sesuai dengan jumlah variabel yang digunakan dalam penelitian. Selain itu, masing-masing butir memiliki factor loading yang lebih tinggi dari 0,4. Berdasarkan hasil tersebut maka dapat disimpulkan bahwa instrumen penelitian memiliki convergent validity sehingga dapat digunakan untuk analisis selanjutnya.

Pengujian reliabilitas menggunakan metode Cronbach's alpha dengan bantuan program SPSS. Penelitian ini menggunakan nilai koefisien minimal 0,60. Berdasarkan hasil pengujian reliabilitas didapatkan nilai Cronbach's alpha pada semua variabel lebih besar dari 0,7 maka berarti semua variabel dapat dikatakan memiliki reliabilitas yang dapat diterima (lebih dari 0,6) sehingga konsistensi item-item pertanyaan dalam kuesioner reliabel.

\section{Pengujian Hipotesis}

Hipotesis 1: Brand name berpengaruh positif pada persepsi kualitas terhadap produk. Hasil analisis pada Tabel 1 , didapatkan nilai koefisien $\beta=0.703$ dan $p<0.01$, sehingga dapat dikatakan bahwa Ho ditolak dan Ha diterima. Berarti hipotesis 1 terdukung, brand name berpengaruh signifikan pada persepsi kualitas.

\section{Tabel 1}

Hasil Analisis Regresi Pengaruh Brand Name pada Persepsi Kualitas

\begin{tabular}{lccc}
\hline \multicolumn{1}{c}{ Variabel } & Koefisien $(\boldsymbol{\beta})$ & $\mathbf{t}$ & Sig \\
\hline Brand Name & 0.703 & 10.861 & 0.000 \\
$\mathrm{R}^{2}$ & & 0.494 & \\
Adjusted R $^{2}$ & & 0.489 & \\
F $(1,121)$ & & 117.951 & \\
Signifikansi F & & 0.000 & \\
\hline
\end{tabular}

Hipotesis 2: Country of origin berpengaruh positif pada persepsi kualitas terhadap 
produk.

Hasil analisis pada Tabel 2, didapatkan nilai koefisien $\beta=0.293$ dan $\mathrm{p}<0.01$, sehingga dapat dikatakan bahwa Ho ditolak dan Ha diterima. Berarti hipotesis 2 terdukung, country of origin berpengaruh signifikan pada persepsi kualitas.

Tabel 2

Hasil Analisis Regresi Pengaruh Country of Origin pada Persepsi Kualitas

\begin{tabular}{lccc}
\hline \multicolumn{1}{c}{ Variabel } & Koefisien $(\boldsymbol{\beta})$ & $\mathbf{t}$ & Sig \\
\hline Country of Origin & 0.293 & 3.374 & 0.001 \\
$\mathrm{R}^{2}$ & & 0.086 & \\
Adjusted $\mathrm{R}^{2}$ & & 0.078 & \\
$\mathrm{~F}(1,121)$ & & 11.386 & \\
Signifikansi F & & 0.001 & \\
\hline
\end{tabular}

Hipotesis 3: Country of origin berpengaruh positif pada niat beli konsumen.

Hasil analisis pada Tabel 3, didapatkan nilai koefisien $\beta=0.236$ dan $p<0.01$, sehingga dapat dikatakan bahwa Ho ditolak dan Ha diterima. Berarti hipotesis 3 terdukung, country of origin berpengaruh signifikan pada niat beli konsumen.

Tabel 3

\section{Hasil Analisis Regresi Pengaruh Country of Origin pada Niat Beli Konsumen}

\begin{tabular}{lccc}
\hline \multicolumn{1}{c}{ Variabel } & Koefisien $(\boldsymbol{\beta})$ & t & Sig \\
\hline Country of Origin & 0.236 & 2.669 & 0.009 \\
$\mathrm{R}^{2}$ & & 0.056 & \\
Adjusted R $^{2}$ & & 0.048 & \\
F $(1,121)$ & & 7.122 & \\
Signifikansi F & & 0.009 & \\
\hline
\end{tabular}

\section{PEMBAHASAN}

Pengujian hipotesis dengan menggunakan analisis regresi sederhana menunjukkan bahwa tiga hipotesis terdukung $(\mathrm{H} 1, \mathrm{H} 2$ dan $\mathrm{H} 3)$. Hasil analisis menunjukkan bahwa kualitas yang dirasakan dipengaruhi oleh brand name dan country of origin. Selain itu, country of origin juga mempengaruhi niat beli konsumen. Penelitian terdahulu mengenai kualitas yang dirasakan sudah banyak dilakukan oleh peneliti lainnya, tema ini tetap menarik minat penelitian karena ada kepercayaan mengenai pengaruh yang menguntungkan dari kualitas dirasakan bagi kinerja pemasaran. Beberapa pendapat menyetujui bahwa persepsi kualitas bukan yang sebenarnya karena merupakan penilaian konsumen tentang entitas atau layanan keunggulan keseluruhan atau superioritas, dan konsumen sering menilai kualitas suatu produk atau layanan berdasarkan berbagai isyarat informasi yang mereka kaitkan dengan produknya (Yee et al., 2011).

Menurut Tsiotsou (2005) terdapat keyakinan bahwa apabila kualitas yang dirasakan tinggi akan mengarah pada pembelian berulang, dan hal tersebut merupakan pondasi bisnis apa pun. Dengan demikian, pemahaman yang lebih baik tentang hubungan antara persepsi kualitas produk dan keterlibatan produk, kepuasan konsumen dan niat membeli dapat membantu untuk mengembangkan model pengambilan keputusan konsumen. Dalam penelitiannya, Tsiotsou menyelidiki hubungan antara perbedaan persepsi kualitas dan keterlibatan produk, kepuasan konsumen dan niat membeli dengan penelitian dilakukan di kalangan konsumen sepatu olahraga. Hasilnya menunjukkan bahwa persepsi terhadap kualitas produk secara signifikan 
terkait dengan semua variabel yang diteliti (involvement, satisfaction, dan purchase intentions). Namun, kualitas yang dirasakan menjelaskan lebih banyak varians dalam kepuasan keseluruhan daripada keterlibatan produk dan niat membeli.

Saleem et al., (2015) berpendapat bahwa ada banyak faktor yang mempengaruhi perilaku pembelian konsumen untuk mencapai target pelanggan secara efisien, namun pemasar tidak dapat mengontrol, seperti faktor individu, sosial, dan psikologis sehingga faktor-faktor tersebut harus dipertimbangkan. Dalam hal pengaruhnya terhadap niat beli, produk yang dirasakan kualitasnya secara langsung dapat mempengaruhi niat beli. Tentunya pelanggan memiliki beberapa persepsi tentang kualitas produk, harga dan gaya sebelum mereka pergi untuk membeli suatu produk. Setelah menggunakan produk, niat beli meningkat dan juga menurun, karena memiliki hubungan langsung yang saling mempengaruhi. Jika kualitas tinggi, maka niat beli akan tinggi. Pelanggan menganggap persepsi kualitas sebagai konsep yang lebih spesifik berdasarkan fitur produk dan layanan, sementara perusahaan dapat memiliki tingkat kontrol atas kualitas. Dapat disimpulkan, apabila persepsi kualitas dianggap sebagai penilaian keseluruhan, maka kualitas yang dirasakan dapat dipahami sebagai sumber kepuasan pelanggan. Dalam penelitian Saleem et al., (2015) yang dilakukan, hasil penelitian mereka menemukan bahwa konsumen memberikan preferensi terhadap kualitas produk. Konsumen menilai kualitas produk dalam hal daya tahan, kehandalan dan keberlanjutan. Hasilnya juga menunjukkan bahwa kepuasan pelanggan memang bertindak sebagai perantara parsial, dan kualitas yang dirasakan memiliki hubungan positif langsung dengan niat pembelian dan kepuasan pelanggan. Dalam hal implikasi manajerial, penelitian tersebut menegaskan bahwa kualitas merupakan kontributor penting dalam kepuasan pelanggan, dan seharusnya tidak hanya menilai perbaikan pada kepuasan pelanggan saja namun juga niat untuk memperbaiki persepsi pelanggan terhadap kualitas produk secara keseluruhan dan untuk meningkatkan persepsi konsumen. Kemudian penting juga untuk meyakinkan pelanggan bahwa mereka mendapatkan kualitas tinggi dari perusahaan sehingga itu menjadi tujuan utama kampanye iklan perusahaan. Dalam lingkungan yang kompetitif, manajer seharusnya tidak hanya fokus pada kualitas produk tapi juga menilai faktor-faktor lainnya. Kepuasan akan tercermin dalam evaluasi pelanggan dan niat beli sehingga ada pertukaran yang mungkin dibutuhkan antara meningkatkan kualitas dan meningkatkan kepuasan.

Faktor negara asal produk sangat penting, dan erat kaitannya dengan brand name. Jika brand name sangat penting bagi sebuah pertukaran bisnis, maka dengan melihat hasil analisis country of origin dapat dikatakan memiliki peran yang sama pentingnya. Brand name dapat dikatakan sebagai aset yang berharga bagi organisasi bisnis. Menurut Ardestani \& Afshar (2015) brand name merupakan panduan bagi calon konsumen. Dalam kaitannya dengan banyaknya produk yang ada di pasaran, tanpa brand name sebuah produk tidak dapat mengkomunikasikan fungsinya sendiri atau nilai moneternya kepada calon konsumen. Dengan adanya brand name, akan memudahkan calon konsumen untuk memberi nilai bagi suatu produk karena calon konsumen mendapatkan suatu panduan persepsi. Hal ini membantu calon konsumen untuk memecahkan kebingungan mereka saat menghadapi banyaknya pilihan produk. Banyak penelitian terdahulu menguji tentang country of origin dan brand name.

Saat calon konsumen menghadapi kebingungan dengan banyaknya variasi produk, mereka bisa memanfaatkan brand name dan country of origin sebagai fungsinya, yaitu mengatur pilihan calon konsumen ditengah kebingungan mereka, dan membantu dalam mengambil keputusan. Hasil analisis regresi diatas juga menunjukkan bahwa faktor negara asal mempengaruhi niat beli konsumen, hal ini sejalan bahwa calon konsumen akan mencari produk 
yang dapat memenuhi harapan dan kebutuhan. Persepsi terhadap negara asal produk akan mempengaruhi keputusan mereka. Misalnya, produk-produk dari Eropa secara umum dipersepsikan memiliki ketahanan yang lebih baik dibanding produk dari negara Asia. Dengan memperhatikan kedua variabel tersebut maka bagi calon konsumen hal itu akan menyederhanakan seleksi produk, dan mempersingkat proses pengambilan keputusan pembelian.

\section{PENUTUP}

Adapun hasil penelitian dapat disimpulkan sebagai berikut:

1. Persepsi kualitas terhadap produk dipengaruhi oleh brand name dan country of origin produk

2. Niat beli konsumen dipengaruhi oleh country of origin produk. Mengamati perilaku pembelian konsumen adalah hal yang menarik.

Penelitian mengenai country of origin memang sangat menarik, dan terdapat beberapa isu yang masih perlu dikembangkan dalam penelitian. Menurut kajian bertema country of origin yang dilakukan oleh Dinnie (2003), ada beberapa isu di masa datang yang dapat dikaji lebih dalam, yaitu:

1. Perlu dilakukan kajian lebih lanjut mengenai pengaruh country of origin dalam kaitannya dengan layanan dan tidak secara eksklusif terkait dengan produk nyata saja. Dapat dicontohkan misalnya apakah kewarganegaraan yang terkait dengan penyedia layanan akan mempengaruhi pengambilan keputusan konsumen. Ini menjadi area yang tidak diteliti.

2. Metodologi penelitian kualitatif tidak banyak dilakukan dibandingkan dengan teknik kuantitatif. Penerapan teknik kualitatif dapat berkontribusi untuk kemajuan konseptual lebih lanjut untuk pengembangan literatur country of origin.

3. Penelitian lebih lanjut diperlukan untuk mengetahui apakah efek country of origin beroperasi secara berbeda sesuai karakteristik sosio-ekonomi/psikografis.

4. Konsep citra negara membutuhkan penyempurnaan lebih lanjut agar bisa mendapatkan identifikasi dan pengukuran citra negara yang kuat. Hal ini tentu saja memerlukan dimensi budaya untuk dipertimbangkan saat memusatkan perhatian pada citra negara, literatur identitas nasional telah diabaikan sejauh ini oleh hampir semua penelitian, terlepas dari kenyataan bahwa budaya merupakan isu sentral dalam literatur identitas nasional.

5. Diperlukan adanya penelitian untuk memeriksa hubungan antara manajemen merek dan citra negara asal.

6. Penggunaan etnosentrisme sebagai dasar untuk segmentasi pemasaran perlu diselidiki lebih lanjut, karena memiliki implikasi langsung untuk kampanye yang bertujuan mendorong konsumen untuk membeli barang-barang produksi lokal daripada barangbarang buatan luar negeri.

7. Sebagian besar penelitian mengenai negara asal adalah dalam kategori fast moving consumer good, dan berfokus pada barang-barang konsumen seperti televisi, oven microwave, mobil, dll. Perlu dilakukan kajian untuk kategori produk lainnya.

8. Pertanyaan tentang apakah efek country of origin berfungsi secara berbeda pada level low involvement dibandingkan dengan produk atau layanan dengan level high involvement. Perlu penelitian secara mendalam untuk level low involvement dan high involvement ini. 
Menurut peneliti, beberapa saran untuk penelitian selanjutnya dari penelitian ini adalah:

1. Perlunya penambahan variabel lain untuk diteliti

2. Penambahan jumlah sampel untuk penelitian dan memperhatikan keragaman responden

3. Memasukkan karakteristik sosio-demografis dalam analisis

4. Menggunakan metode penelitian yang lain, misalnya dengan teknik eksperimen

\section{REFERENSI}

Aaker, D. A. (1991). Managing Brand Equity. New York: The Free Press.

Achmad, N., \& Istiqomah. (2014). Faktor-Faktor Yang Berpengaruh Terhadap Evaluasi Konsumen Pada Produk Laptop Mahasiswa Di Yogyakarta.

Ardestani, A. S., \& Afshar, M. (2015). Relationship between Brand Personality, Attitude and Commitment to Brand Name ( Case study: Dairy Industry of Iran ). European Online Journal of Natural and Social Sciences, 4(1), 899-906.

Cooper, D. R., \& Schindler, P. S. (2006). Business Research Methods. McGraw-Hill Irwin.

Dinnie, K. (2003). Country-of-origin 1965-2004 : A Literature Review. Journal of Customer Behaviour, 1-44.

Ghazali, M., Said Othman, M., Zahiruddin Yahya, A., \& Sarif Ibrahim, M. (2008). Products and Country of Origin Effects: The Malaysian Consumers' Perception Introduction: Country of Origin Effect in the Global Market. International Review of Business Research Papers, 4(2), 91-102.

Hair, J. F., Black, B., \& Babin, B. (2006). Multivariate Data Analysis (6th Edition) (6th ed.). Prentice Hall.

Järveläinen, K. (2012). Effects of Country of Origin on Consumer Product Evaluations: Finnish Clothing Products in the Minds of Russian Tourists. Lappeenranta University of Technology - LUT.

Johnson, R., \& Bruwer, J. (2007). Regional brand image and perceived wine quality: the consumer perspective. International Journal of Wine Business Research, 19(4), 276-297. http://doi.org/10.1108/17511060710837427

Krisjanti, W. M. N. (2007). Evaluasi Pengaruh Country-Of-Origin, Merek, Dan Harga Pada Pembelian Produk Susu Import. Kinerja, 11(1).

Listiana, E. (2013). Pengaruh Country Of Origin terhadap Perceived Quality Dengan Moderasi Etnosentris Konsumen. Jurnal Administrasi Bisnis, 8(1), 25-51.

Luo, M. M. (Grace). (2011). Country-of-Origin ( COO ) Effect on Chinese Consumers ' Evaluation of New Zealand Milk Powder. Auckland University of Technology.

Nugroho Sahid Susilo, Rokhima, R., \& Indriyo, G. (n.d.). The Impacts of Country of Origin, Product Involvement, and Product Familiarity on Product Evaluation.

Qader, I. K. A., \& Zainuddin, Y. (2010). Intention to Purchase Green Electronic Products : The Consequences of Perceived Government Legislation, Media Exposure and Safety \& Health Concern and the Role of Attitude as Mediator. International Journal of Innovation, Management and Technology, 1(4), 432-440.

Saleem, B. A., Ghafar, A., Ibrahim, M., Yousuf, M., \& Ahmed, N. (2015). Product Perceived Quality and Purchase Intention with Consumer Satisfaction. Global Journal of Management and Business Research: E Marketing, 15(1). 
Severi, E., \& Ling, K. C. (2013). The Mediating Effects of Brand Association , Brand Loyalty , Brand Image and Perceived Quality on Brand Equity. Asian Social Science, 9(3), 125137. http://doi.org/10.5539/ass.v9n3p125

Suria, N. N., Kusumawati, A., \& Pangestuti, E. (2016). Pengaruh Country of Origin terhadap Citra Merek dan Dampaknya Bagi Keputusan Pembelian (Studi Pada Konsumen Uniqlo di Jakarta ). Jurnal Administrasi Bisnis (JAB)|, 38(1), 148-156.

Tsiotsou, R. (2005). Perceived Quality Levels and their Relation to Involvement, Satisfaction , and Purchase Intentions. Marketing Bulletin, 16, 1-10.

Xiaoling Hu, Leeva Li, Charlene Xie, J. Z. (2008). The effects of country-of-origin on Chinese consumers' wine purchasing behaviour. Journal of Technology Management in China, 3(3), 292-306. http://doi.org/10.1108/17468770810916195

Yee, C. J., San, N. C., Barat, B., Perak, D. R., Sultan, J., \& Shah, A. (2011). Consumers ' Perceived Quality, Perceived Value and Perceived Risk Towards PurchaseDecision on Automobile. American Journal of Economics and Business Administration, 3(1), 47-57. 